Original Paper http://ajol.info/index.php/ijbcs http://indexmedicus.afro.who.int

\title{
Ethnobotanical study and antioxidant activity of anti-hepatitis plants extracts of the COMOE province, Burkina Faso
}

\author{
Ernest Nogma SOMBIE ${ }^{1 *}$, André TIBIRI ${ }^{1,2}$, Jotham Yhi-Pénê N'DO ${ }^{1}$, \\ Tata Kadiatou TRAORE ${ }^{3}$, Noufou OUEDRAOGO ${ }^{2}$, Adama HILOU ${ }^{1}$, \\ Pierre Innocent GUISSOU ${ }^{2,3}$ and Odile Germaine NACOULMA ${ }^{1}$
}

\author{
${ }^{1}$ Laboratory of Biochemistry and Applied Chemistry (LABIOCA) / University of Ouagadougou, 03 BP 848 \\ Ouagadougou 03, Burkina Faso. \\ ${ }^{2}$ Institute for Research in Health Sciences (IRSS / CNRST), Department of Medicine and Traditional \\ Pharmacopoeia (MEPHATRA-PH), 03 BP 7192 Ouaga 03, Burkina Faso. \\ ${ }^{3}$ Doctoral School of Health / University of Ouagadougou, PO Box 7021, Burkina Faso. \\ *Corresponding author; E-mail: ernestsombie@yahoo.fr; Tel.: +226 70015626, +226 76765659
}

\begin{abstract}
Acute hepatitis B and its complications cause 800000 and 3300 deaths each year respectively in the world and in Burkina Faso. In Burkina Faso, the majority of the population uses medicinal plants to treat hepatitis. The present study consisted to identify the medicinal plants used to treat hepatitis in COMOE province of Burkina Faso. Extracts from the most cited species were screened for their antioxidant capacity (using ABTS and FRAP methods) and their content in phenolics. Thirty-two anti-hepatitis species belonging to 29 genera and 20 families were recorded in the COMOE province. Extracts from Diospyros mespiliformis and Terminalia macroptera showed the best antioxidant activities $(1.17 \pm 0.00 \mathrm{mM}$ TEAC/g and $70.77 \pm 0.4 \mu \mathrm{M}$ $\mathrm{ET} / \mathrm{g} ; 1.09 \pm 0.03 \mathrm{mM} \mathrm{TEAC} / \mathrm{g}$ and $81.17 \pm 0.5 \mu \mathrm{M} \mathrm{TE} / \mathrm{g}$ extract, respectively).The same extracts exhibited the highest total phenolic contents. Low correlation has been obtained between total phenolic contents and antioxidant capacity (TEAC) of the extracts. This finding suggests that non-phenolic antioxidant compounds would be involved in the bioactivity of these species. This study constitutes a contribution in the safeguarding of traditional hepatoprotective medicinal knowledge of COMOE province of Burkina Faso.
\end{abstract}

(C) 2018 International Formulae Group. All rights reserved.

Keywords: Anti-hepatitis plants, antioxidant activity, COMOE province, Burkina Faso.

\section{INTRODUCTION}

Viral hepatitis is a major public health problem (OMS, 2012). Two billion people have been infected worldwide with hepatitis B virus (HBV) and 360 million people are chronic carriers with nearly 800,000 deaths a year (OMS, 2014). Three to four million people contract hepatitis $\mathrm{C}$ every year and nearly 150 million people are chronic carriers with over 500,000 deaths per year (OMS, 2014). In Burkina Faso, acute hepatitis B causes 1,100 deaths; Cirrhosis and primary liver cancer from chronic forms cause respectively 900 and 1,300 deaths per year (WHO, 2004). Modern treatments of viral hepatitis are expensive (Schwierz et al., 2011) and have limited effectiveness by poor tolerance of side effects (Thevenot et al., 
2006). The only vaccine existing, the hepatitis $B$ vaccine remains inaccessible to the poor free of the population in terms of its expensive cost. This situation explains the interest of evaluating the natural substances of plants traditionally used (Mukazayire et al., 2011). The present study consisted in identifying the anti-hepatic medicinal plants used in certain localities of the COMOE province in Burkina Faso. Viral attack of liver cells results in increased production of free radicals that cause liver damage (Twedt, 2006). Plant antioxidants that have the property of trapping free radicals can be a therapeutic way in viral hepatitis. The species most quoted by the surveyed were therefore evaluated for their antioxidant capacity as well as their content of phenolic compounds: Cassia sieberiana DC. (Caesalpiniaceae), Diospyros mespiliformis Hochst ex.A.DC (Ebenaceae), Lophira lanceolata Tiegh.ex Keay (Ochnaceae) Piliostigma thonningii (Schum.) Milne-Redh (Caesalpiniaceae) Sarcocephalus latifolius (Sm.) EABruce (Rubiaceae) And Terminalia macroptera Guill. \& Perr (Combretaceae). The objective of this study was to elucidate the pharmacological mechanism of natural substances action of these extracts in order to consider the formulation of phytomedicines from the enriched extracts.

\section{MATERIALS AND METHODS \\ Ethnobotanical survey \\ Ethnobotanical area of investigation}

The survey was carried out in three communes in the COMOE province, in the cascade region in south-west Burkina Faso: Banfora, Bérégadougou and Moussodougou. The survey area extends between longitude $4^{\circ}$ 67 'and $4^{\circ} 82^{\prime} \mathrm{W}$ and between latitudes $10^{\circ} 73$ 'and $10^{\circ} 85^{\prime} \mathrm{N}$. The area covers an area of 18 $424 \mathrm{~km}^{2}$ with a population of 713059 inhabitants in 2014 according to the National Institute of Statistics and Demography (INSD, 2009). Its population is mainly composed of Dioula, Senoufo, Goin, Turka, Fulfuldé, Karaboro, Komono, Mossi and Tousian. The region is characterized by a South-Sudanian climate. The landscape is made up of wooded and arboreous savannas, clear forests and gallery, grass carpet.

\section{Data gathering}

The ethnomedical survey consisted of an open, semi-structured interview in which the interviewee was asked to answer exhaustively the questions asked by the interviewer. The questions were asked in the Dioula, Turka or French languages. The themes dealt with mainly relate to the local and scientific names of the plant, its part used, its preparation, its administration, the pathologies treated, the type (s) and the duration of the treatment. The interviewee concerned was mostly traditional healers or herbalists. The diagnosis made by the interviewee was mainly based on jaundice and other clinical factors such as asthenia, fever, headache, insomnia. Field trips were made in the presence of the interviewee, to see the species mentioned, to take their GPS coordinates, to photograph them and to collect specimens. Specimens of the indicated plant species were harvested from the site and subsequently identify at the UFR/SVT Ecology Laboratory at Ouaga University Professor Joseph Ki Zerbo. Six species were selected according to the citation index and according to a bibliographic review for the study of biological activities.

\section{Determination of antioxidant activities and levels of phenolic compounds \\ Plant material}

The roots and leaves of Cassia sieberiana DC., Piliostigma thonningii (Schum.) Milne-Redh, Sarcocephalus latifolius (Sm.) EABruce, leaves of Diospyros mespiliformis Hochst ex.A.DC, root bark of Lophira lanceolata Tiegh.ex Keay and Terminalia macroptera Guill. And Perr, were harvested in November 2012 in the COMOE province of Burkina Faso, then dried out of the sun and pulverized into fine powder by a blade mill (Gladiator East, 1931 Type BN 1 Mach 40461 1083).

\section{Extraction}

The extraction modes are the aqueous infusion for the leaves of Diospyros 
mespiliformis and aqueous decoctions for the eight other plant samples.

\section{Methods for determining antioxidant activities \\ ABTS (2'2,azino-bis-(3-ethylbenzothiazoline)-6- sulfonic acid) method}

The TEAC test (Trolox Equivalent Antioxidant Capacity) was determined by the ABTS test ( $\operatorname{Re}$ et al., 1999). ABTS is dissolved in water at a concentration of $7 \mathrm{mM}$. The ABTS $\left(\mathrm{ABTS}^{+}\right)$cation radical is produced by reacting the stock solution of ABTS with $2.45 \mathrm{mM}$ of potassium persulfate and the mixture placed in the dark at room temperature for $12-16 \mathrm{~h}$ prior to use. The reaction mixture consisted of $1.0 \mathrm{~mL}$ of diluted $\mathrm{ABTS}^{+}$solution and $10 \mu \mathrm{L}$ of extract or Trolox (1 mM concentration standard in ethanol). We incubated it for 30 minutes at room temperature and the absorbance read at $734 \mathrm{~nm}$. Negative control was consisted of distilled water. All measurements were carried out in three independent tests. The inhibition percentage was calculated according to the following formula:

$\%$ Inhibition $=[(\mathrm{A} 0-\mathrm{A} 1) / \mathrm{A} 0] \times 100$

The 50\% inhibitory concentration $\left(\mathrm{IC}_{50}\right)$ was determined and the anti-radical power (ARP) was given by the following formula: $\mathrm{ARP}=\left[1 / \mathrm{IC}_{50}\right] \times 100$.

The antioxidant power (TEAC) was calculated according to the formula: TEAC $=$ (ARP product)/(ARP trolox)

\section{Ferric Reducing Antioxidant Power (FRAP) method}

The method described by Hinneburg et al. (2006) was used. $1.25 \mathrm{~mL}$ of phosphate buffer $(0.2 \mathrm{M}, \mathrm{pH}$ 6.6) are added to a test tube containing $0.5 \mathrm{~mL}$ of extract $(0.1 \mathrm{mg} / \mathrm{mL})$ and then $1.25 \mathrm{~mL}$ of potassium hexacyanoferrate $\left[\mathrm{K}_{3} \mathrm{Fe}(\mathrm{CN})_{6}\right] 1 \%$ in water. The whole is heated at $50{ }^{\circ} \mathrm{C}$ in a water bath for 30 minutes. Then, $1.25 \mathrm{~mL}$ of trichloroacetic acid (10\%) was added and the mixture was centrifuged at $2000 \mathrm{rpm}$ for 10 minutes. Three $0.625 \mathrm{~mL}$ aliquots were taken from the supernatant and placed in 3 eppendorf tubes to which was added $0.625 \mathrm{~mL}$ of distilled water and then $0.125 \mathrm{~mL}$ of freshly prepared $0.1 \% \mathrm{FeCl}_{3}$ in distilled water. A blank without a sample was prepared under the same conditions. The reading was carried out at $700 \mathrm{~nm}$ against a standard trolox curve $(\mathrm{y}=0.6237 \mathrm{x}+0.0387$, $\left.\mathrm{R}^{2}=0.9926\right)$ and the reducing powers were expressed in $\mu \mathrm{mol} \mathrm{ET} / \mathrm{g}$ dry extract.

\section{Determination of phenolic compounds Determination of total phenolics}

The total phenolic compounds were assayed according to the method of Singleton et al. (1999). The phenolic compounds react with the Folin Ciocalteu reagent (FCR) in an alkaline medium, forming a blue colored complex whose maximum absorption is at 760 $\mathrm{nm}$. The reaction mixture consists of $1 \mathrm{~mL}$ of extract, $1 \mathrm{~mL}$ of $2 \mathrm{~N} \mathrm{FCR}$ and $3 \mathrm{~mL}$ of a $20 \%$ sodium carbonate solution. It was allowed to stand at room temperature for 40 minutes and then the absorbance was measured at $760 \mathrm{~nm}$ on the spectrophotometer (Agilent 8453) against a tannic acid standard curve (1-5 $\mu \mathrm{g} / \mathrm{mL})$. Three independent tests were conducted.

\section{Determination of tannins}

The method described by Tibiri et al. (2007) was used. The tannins were precipitated by formation of complex with the polyvinyl polypyrrolidone (PVPP). $100 \mathrm{mg}$ of PVPP were sufficient to complex $2 \mathrm{mg}$ of total phenolics. The quantity of PVPP necessary to complex the total phenols determined as described above was added to 1 $\mathrm{mL}$ of extract of concentration $0.5 \mathrm{mg} / \mathrm{mL}$. The mixture was vortexed, kept at $4{ }^{\circ} \mathrm{C}$ for 15 $\min$ and then centrifuged at $3000 \mathrm{~g}$ for 10 min. The supernatant contains the phenolic compounds other than the tannins, these having been precipitated by the PVPP. A metering tube was made as for total phenolics. After 40 minutes, it was centrifuged and the absorbance of the supernatant was measured at $760 \mathrm{~nm}$. The tannin content was determined by differentiating between the first value of the total phenolic compounds (which contained the tannins) and the second value of the total phenolic compounds (in the absence of tannins). 


\section{Dosage of total flavonoids}

The flavonoid assay was carried out according to the method described by AbdelHameed (2009). $100 \mu \mathrm{L}$ of extract (10 $\mathrm{mg} / \mathrm{mL}$ ) in methanol were mixed with $100 \mu \mathrm{L}$ of $2 \%$ aluminum trichloride in methanol and a drop of acetic acid and the volume was then brought to $5 \mathrm{~mL}$ with methanol. After $40 \mathrm{~min}$, the absorbance was read at $415 \mathrm{~nm}$. Positive control was performed with quercetin. The absorbance was read against a quercetin standard curve. The amount of flavonoids in the plant extract was expressed in gram quercetin equivalent $(\mathrm{QE})$ per $100 \mathrm{~g}$ of plant powder.

\section{Statistical analysis of data}

The survey results were recorded and processed with the Sphinx V5 software. All the experiments were performed in triplicate $(\mathrm{n}=3)$ and the results were expressed as mean \pm SD. The statistical study was carried out by the statistical software XLSTAT V.7.1. Using ANOVA followed by the Fisher LSD test for multiple comparisons. The differences were considered significant at the probability threshold of $5 \%$ if $\mathrm{p}<0.05$.

\section{RESULTS}

\section{Ethnobotanical survey}

Twenty-six (26) people, including 22 men, agreed to submit to the questionnaire. The interviewee age ranged between 25 and 75 years. More than $60 \%$ of respondents were old of 50 years with at least 10 years of experience in traditional medicine. Thirty-two species (Table 1), belonging to 29 genera and 20 families, were recorded. The most representative families were Caesalpiniaceae, Combretaceae, Meliaceae, Asteraceae and Mimosaceae (Table 2). The listed hepatotropic plants are predominantly trees and shrubs. Citation index vary between 1 and 13. Cochlospermum tinctorium is the most commonly used species, followed by $C$. sieberiana and S. latifolius (Table 1).

Different organs were used by traditional healers or herborists to treat liver disease. Leaves were the most used organs, $46 \%$, followed by roots $34 \%$ (Figure 2). Fruits and stem bark were little used. The decoction (74\%) was the most used method of preparation (Figure 3). Infusion (14\%) and maceration $(10 \%)$ were little used, while other forms of preparation ( $2 \%$ ) were also little used (Figure 3).

\section{Antioxidant activities and levels of phenolic compounds}

The tests carried out reveal that the various extracts possess antioxidant powers and that they contain phenolic compounds (Table 3).

The antioxidant activities of the extracts varies between $1.17 \pm 0.00$ and $0.05 \pm$ $0.01 \mathrm{mM}$ for the ABTS method and between $83 \pm 0.6$ and $46.88 \pm 3.3 \mu \mathrm{M}$ TE/g extract for the FRAP method. The extract of the root bark of $P$. thonningii revealed the strongest reducing power (FRAP) while the extract of the roots of $S$. latifolius showed the lowest reducing power. The $D$. mespiliformis leaves and the roots of $S$. latifolius extracts gave the strongest and the lowest antioxidant capacity (TEAC) respectively. Extracts of $D$. mespiliformis and T. macroptera showed high significant antioxidant capacities (TEAC) (P $<0.05)$ compared with the trolox $(1 \mathrm{mM})$ used as reference compound. The other extracts showed a significantly lower antioxidant capacity $(\mathrm{P}<0.05)$ than that of the trolox. Extracts of $S$. latifolius showed the weakest antioxidant activities (ABTS, FRAP).

The total phenolics, tannins and flavonoids contents respectively ranged from $32.44 \pm 0.10$ to $1.86 \pm 0.11 \mathrm{~g} \mathrm{EAT} / 100 \mathrm{~g}$ dry matter, from $20.35 \pm 0.61$ to $1.36 \pm 0.14 \mathrm{~g}$ EAT/100 g dry matter and $5.22 \pm 0.41$ to 0.11 $\pm 0.004 \mathrm{~g} \mathrm{EQ} / 100 \mathrm{~g}$ dry matter. The extract of $T$. macroptera showed the highest total phenolics, tannins and flavonoids. The lowest levels of total phenolics and tannins were obtained with the roots of $S$. latifolius. The lowest content of flavonoids was obtained with the roots of $P$. thonningii. Extracts of $D$. mespiliformis and T. macroptera showed interesting antioxidant activities with the ABTS and FRAP method. The same extracts also gave the highest total phenolic. 
Table 1: Anti-hepatic medicinal plants identified during the ethnomedical survey.

\begin{tabular}{|c|c|c|c|c|}
\hline Plant Species & Local Name & Type of plant & Organ used/ preparation/mode used & $\begin{array}{l}\text { Citation } \\
\text { index }\end{array}$ \\
\hline Anogeissus leiocarpus (DC.) G.Perr. (Combretaceae) & Gombliri (Turka) & Tree & Leaves/Decoction/Drink & 1 \\
\hline Argemone mexicana L. (Papaveraceae) & & Grass & Leaves/Decoction/Drink & 1 \\
\hline Azadirachta indica.Juss (Meliaceae) & Neem (Français) & Tree & Leaves/Decoction/Drink & 1 \\
\hline Carica papaya L. (Caricaceae) & Papayer (Français) & Tree & $\begin{array}{l}\text { Yellow leaves/Decoction/Drink } \\
\text { Fruits/Boil/Eating }\end{array}$ & $\begin{array}{l}2 \\
2\end{array}$ \\
\hline Cassia occidentalis L. (Caesalpiniaceae) & Kinkéliba(Français) & Shrub & Leaves/Decoction/Drink & 1 \\
\hline Cassia siamea.Lam (Caesalpiniaceae) & Cassia (Français) & Tree & Leaves/Decoction/Drink & 1 \\
\hline Cassia sieberiana DC. (Caesalpiniaceae) & Sindian yiri (Dioula) & Tree & $\begin{array}{l}\text { Leaves/Decoction/Drink } \\
\text { Root/Decoction/Drink }\end{array}$ & $\begin{array}{l}4 \\
1\end{array}$ \\
\hline Cassytha filiformis L. (Lauraceae) & & Shrub & Aerial part/Maceration /Drink & 1 \\
\hline Chrysantellum americanum L. (Asteraceae) & & Shrub & Aerial part/ Infusion of powder/Drink & 1 \\
\hline Citrus aurantifolia (Christm) Swingle (Rutaceae) & $\begin{array}{l}\text { Citronnier } \\
\text { (Français) }\end{array}$ & Tree & Fruit + leaves of kinkeliba/ Decoction/Drink & 1 \\
\hline Cochlospermum planchonii MS. (Cochlospermaceae) & N’Dribala (Dioula) & Shrub & Roots/Decoction/Drink & 1 \\
\hline Cochlospermum tinctorium A.Rich. (Cochlospermaceae) & Faux cotonnier (Français) & Shrub & $\begin{array}{l}\text { Roots/Decoction/Drink } \\
\text { Root/Infusion/Drink } \\
\text { Roots/Maceration/Drink }\end{array}$ & $\begin{array}{l}8 \\
3 \\
2\end{array}$ \\
\hline Combretum fragrans F.Hoffm. (Combretaceae) & Vapélosié (Dagara) & Tree & Leaves/Decoction/Drink & 1 \\
\hline Commelina benghalensis L. (Commelinaceae) & Barbar (Turka) & Grass & Aerial part/Decoction/Drink & 1 \\
\hline Detarium microcarpum Guill. \& Perr. (Caesalpiniaceae) & & Tree & Roots/Maceration/Drink & 1 \\
\hline
\end{tabular}


E. N. SOMBIE et al. / Int. J. Biol. Chem. Sci. 12(3): 1308-1319, 2018

\begin{tabular}{|c|c|c|c|c|}
\hline Diospyros mespiliformis Hochst ex.A.DC. (Ebenaceae) & Sounsou yiri (Dioula) & Tree & Leaves/Infusion of powder/Drink & 1 \\
\hline Entada africana Guill et Perr (Mimosaceae) & Sama nèrè (Dioula) & Shrub & Roots/Infusion/Drink & 2 \\
\hline Guiera senegalensis J.F.Gmel. (Combretaceae) & Counglê yiri (Dioula) & Shrub & Leaves/Infusion of powder/Enema and drink & 1 \\
\hline Khaya senegalensis (Desr) A.Juss. (Meliaceae) & Caïcedra (Français) & Tree & Stem bark/Decoction /Drink & 1 \\
\hline Lophira lanceolata Tiegh.ex Keay. (Ochnaceae) & Nwali (Turka) & Tree & Roots bark/ Decoction/Drink & 1 \\
\hline Mangifera indica L. (Anacardiaceae) & Manguier (Français) & Tree & Leaves/Decoction/Drink & 1 \\
\hline Parkia biglobosa (Jacq).R.Br.ex G.Don. (Mimosaceae) & Néré (Français) & Tree & Roots/Infusion/Drink & 1 \\
\hline \multicolumn{5}{|l|}{ Phyllanthus amarus Schumacher. (Euphorbiaceae) } \\
\hline $\begin{array}{l}\text { Piliostigma thonningii } \quad \text { (Schum.) } \\
\text { (Caesalpiniaceae) }\end{array}$ & & Grass & Leaves/Decoction/Drink & 1 \\
\hline \multirow[t]{3}{*}{ Pterocarpus erinaceus Poir. (Fabaceae) } & Nyamma yiri (Dioula) & Shrub & Leaves/Decoction/Drink & 1 \\
\hline & & & Roots/Decoction/Drink & 1 \\
\hline & Balan yiri (Dioula) & Tree & Leaves/Decoction/Drink & 1 \\
\hline Saba senegalensis (A.DC.) Pichon var. (Apocynaceae) & Zaban yiri (Dioula) & Creeper & Roots/Infusion/Drink & 1 \\
\hline \multirow[t]{2}{*}{ Sarcocephalus latifolius (Sm.) E.A.Bruce (Rubiaceae) } & Bâti yiri (Dioula) & Tree & Roots/Decoction/Drink & 1 \\
\hline & & & Leaves/Decoction/Drink & 3 \\
\hline Securidaca logepedunculata Fers (Polygalaceae) & Djoro (Dioula) & Shrub & Roots bark/Decoction/Inhalation and enema & 2 \\
\hline \multirow[t]{2}{*}{ Tamarindus indica L. (Caesalpiniaceae) } & Tamarinier (Français) & Tree & Fruits/Maceration/Drink & 1 \\
\hline & & & Leaves/Decoction/Drink & 1 \\
\hline Terminalia macroptera Guill. \& Perr. (Combretaceae) & Kougali (Turka) & Tree & Roots bark/ Decoction/Drink & 1 \\
\hline Vernonia colorata (Wild.) Drake (Asteraceae) & Koisafine (Turka) & Shrub & Leaves/Decoction/Drink & 1 \\
\hline Zingiber officinale Rosc. (Zingiberaceae) & Gnamakou (Dioula) & Grass & Clove/Maceration/Drink & 1 \\
\hline
\end{tabular}


Table 2: Taxonomic diversity of hepatoprotective plants checked off in the COMOE.

\begin{tabular}{lll}
\hline Families & Number of genres & Number of species \\
\hline Caesalpiniaceae & 4 & 6 \\
Combretaceae & 4 & 4 \\
Meliaceae & 2 & 2 \\
Mimosaceae & 2 & 2 \\
Asteraceae & 2 & 2 \\
Cochlospermaceae & 1 & 2 \\
Others famillies & 14 & 14 \\
Total & 29 & 32 \\
\hline
\end{tabular}

Table 3: Results of the Antioxidant Activities and the Phenolic Compounds of the Extracts.

\begin{tabular}{|c|c|c|c|c|c|c|}
\hline Species & Organs used & $\begin{array}{l}\text { Total phenolic content (g } \\
\text { EAT } / 100 \mathrm{~g} \text { DM) }\end{array}$ & $\begin{array}{l}\text { Total tannin content (g } \\
\text { EAT/100g DM) }\end{array}$ & $\begin{array}{l}\text { Total flavonoid } \\
\text { content }(\mathrm{g} \text { EQ/100g } \\
\text { DM) }\end{array}$ & $\begin{array}{l}\text { Antioxidant } \\
\text { capacities TEAC } \\
\text { in } \mathrm{mM}(\mathrm{ABTS}) \\
\end{array}$ & $\begin{array}{l}\text { Reductive power (FRAP) of the ferric } \\
\text { ion in ferrous ion }(\mu \mathrm{M} \text { ET/g of dry } \\
\text { extract) }\end{array}$ \\
\hline \multirow[t]{2}{*}{ C. sieberiana } & Leaves & $9,89 \pm 0,005^{\mathrm{e}}$ & $7,97 \pm 0,23^{\mathrm{c}}$ & $1,72 \pm 0,07^{\mathrm{c}}$ & $0,11 \pm 0,00^{\mathrm{g}, \mathrm{h}}$ & $79,85 \pm 1,1^{\mathrm{b}}$ \\
\hline & Roots & $8,36 \pm 0,28^{f}$ & $7,18 \pm 0,03^{\mathrm{d}}$ & $0,55 \pm 0,07^{\mathrm{d}, \mathrm{e}}$ & $0,26 \pm 0,03^{\mathrm{e}}$ & $59,12 \pm 1,1^{f}$ \\
\hline D. mespiliformis & Leaves & $16,41 \pm 0,30^{b}$ & $\mathrm{Nd}$ & $\mathrm{Nd}$ & $1,17 \pm 0,00^{\mathrm{a}}$ & $70,77 \pm 0,4^{\mathrm{d}}$ \\
\hline L. lanceolata & Roots bark & $14,16 \pm 0,22^{\mathrm{d}}$ & $12,72 \pm 0,007^{b}$ & $0,3 \pm 0,01^{\mathrm{e}, \mathrm{f}}$ & $0,67 \pm 0,03^{\mathrm{d}}$ & $64,15 \pm 0,5^{\mathrm{e}}$ \\
\hline \multirow[t]{2}{*}{ P. thonningii } & Leaves & $14,98 \pm 1,09^{\mathrm{c}}$ & $12,62 \pm 0,02^{b}$ & $2,17 \pm 0,13^{b}$ & $0,18 \pm 0,03^{\mathrm{f}, \mathrm{g}}$ & $79,92 \pm 0,7^{b}$ \\
\hline & Roots & $5,08 \pm 0,06^{\mathrm{g}}$ & $3,98 \pm 0,004^{\mathrm{e}}$ & $0,11 \pm 0,004^{\mathrm{f}}$ & $0,2 \pm 0,02^{f}$ & $83 \pm 0,6^{\mathrm{a}}$ \\
\hline \multirow[t]{2}{*}{ S. latifolus } & Leaves & $5,12 \pm 0,33^{\mathrm{g}}$ & $4,33 \pm 0,34^{\mathrm{e}}$ & $0,6 \pm 0,09^{d}$ & $0,08 \pm 0,005^{h}$ & $58,62 \pm 0,6^{f}$ \\
\hline & Roots & $1,86 \pm 0,11^{\mathrm{h}}$ & $1,36 \pm 0,14^{\mathrm{f}}$ & $0,45 \pm 0,07^{\mathrm{d}, \mathrm{e}}$ & $0,05 \pm 0,01^{\mathrm{h}}$ & $46,88 \pm 3,3^{g}$ \\
\hline T. macroptera & Roots bark & $32,44 \pm 0,10^{\mathrm{a}}$ & $20,35 \pm 0,61^{\mathrm{a}}$ & $5,22 \pm 0,41^{\mathrm{a}}$ & $1,09 \pm 0,03^{b}$ & $81,17 \pm 0,5^{b}$ \\
\hline Trolox & $\begin{array}{l}------ \\
\end{array}$ & ---------- & '-------------- & ------------------- & $1,00 \pm 0,00^{\mathrm{c}}$ & --------- \\
\hline
\end{tabular}

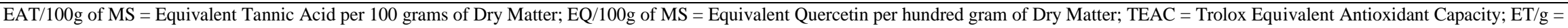

Trolox equivalent per gram of dry extract; Nd: Not determined.

The letters a, b, c, d e, f, g, h indicate the significant differences between the extracts for each test at the probability threshold of $5 \%$ if $\mathrm{p}<0.05$. 


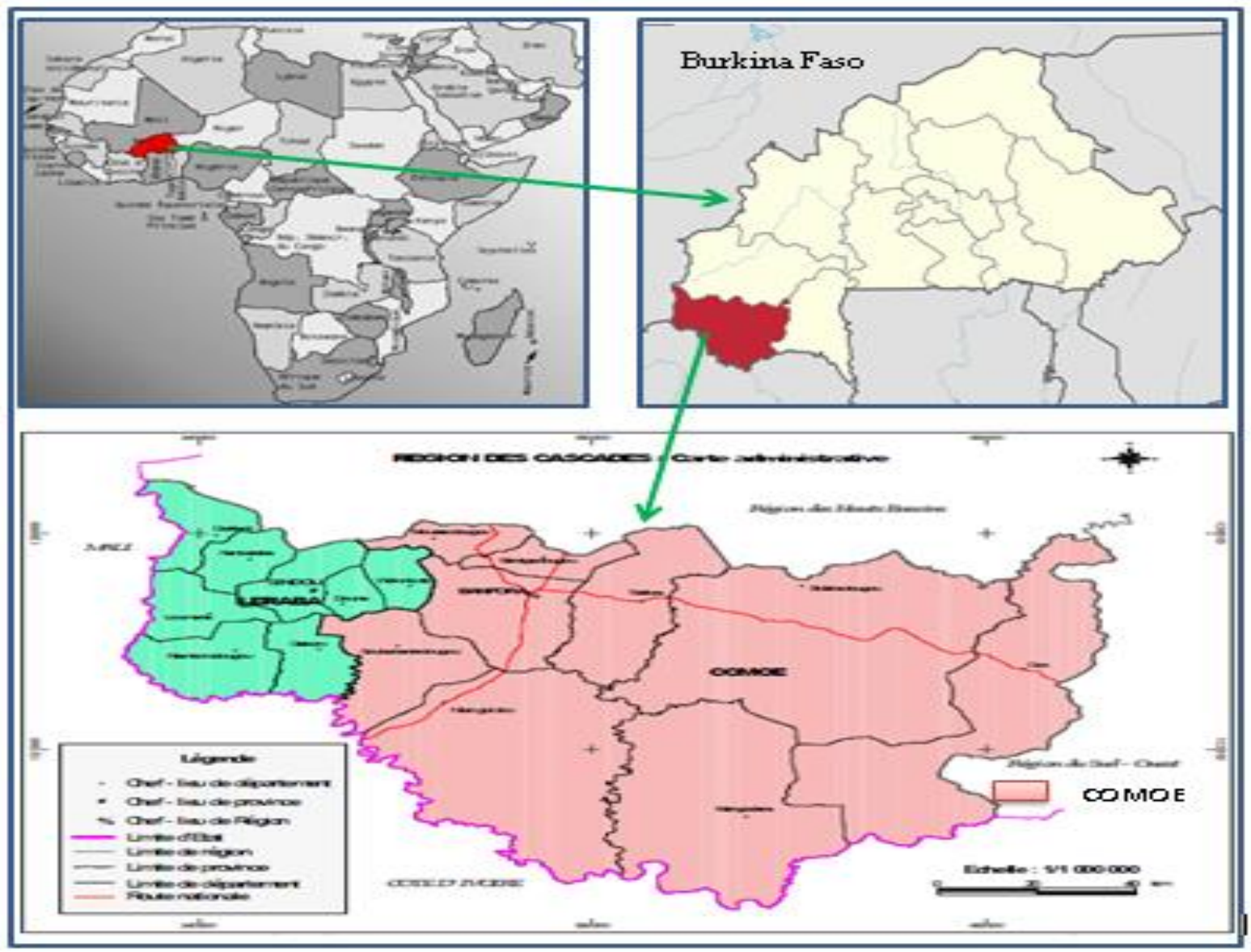

Figure 1: Survey area, Comoe province in the Cascades region: communes of Banfora, Bérégadougou, Moussodougou.

\section{$\%$ organs used}
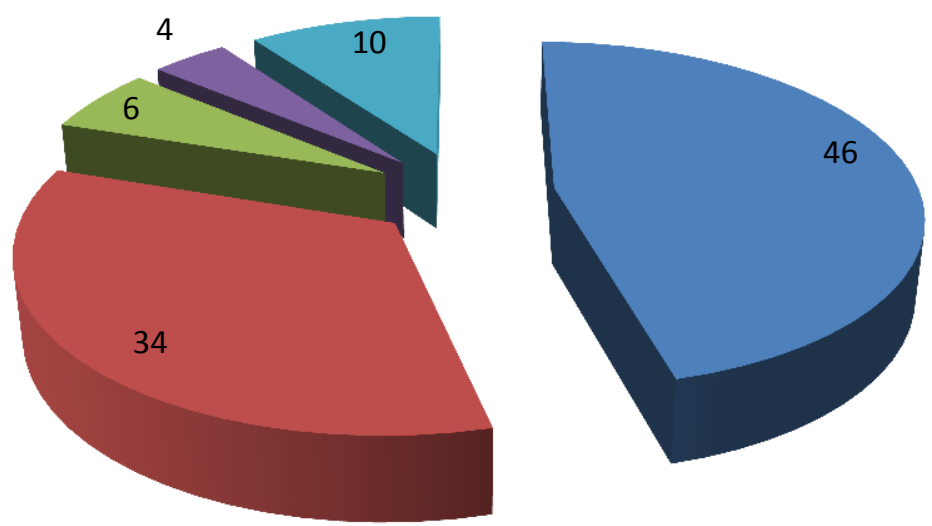

- Leaves

Roots

Fruits

Stem bark

Other

Figure 2: Percentages of the different organs used by the respondents. 


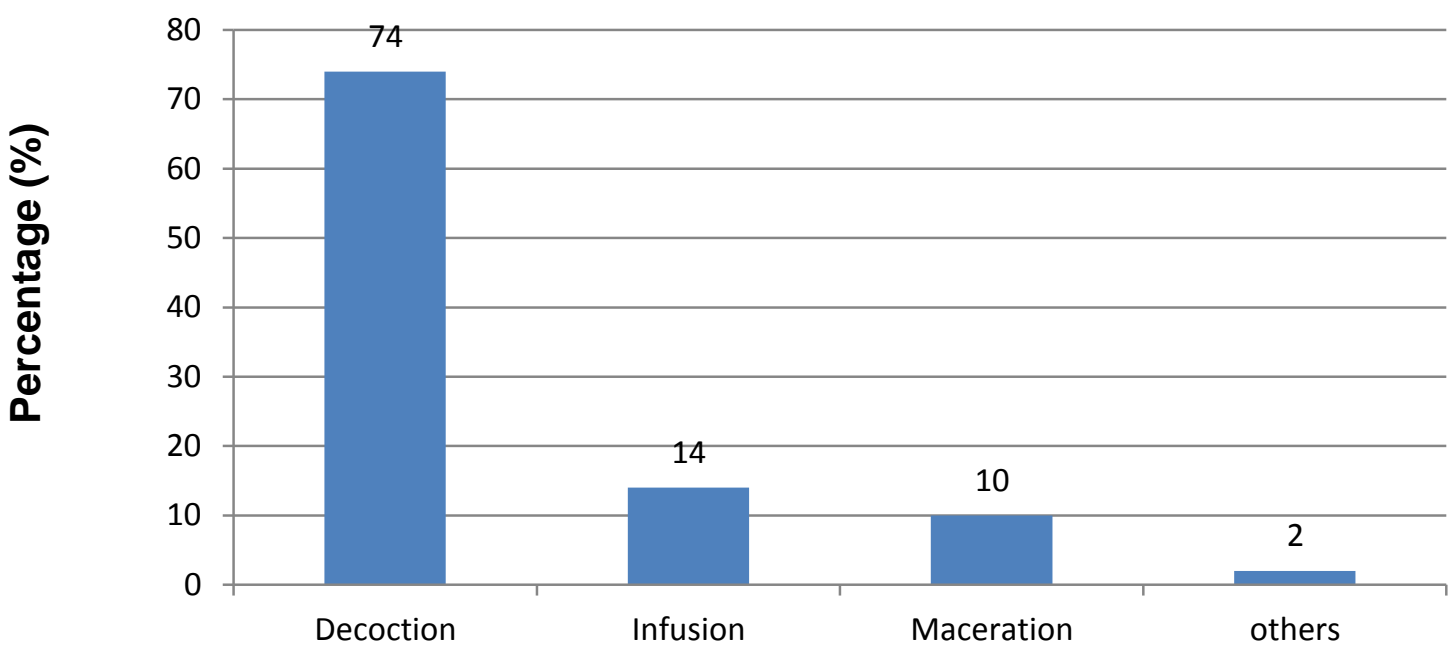

Modes of preparation used

Figure 3: Proportions of the different modes of preparation used by the respondent.

\section{DISCUSSION}

\section{Ethnomedical}

\section{hepatoprotective plants}

The majority of interviewees in these surveys were men. This may be justified not only by the fact that the transmission of knowledge to most indigenous people in the locality (Turka, Goins, Karaboro) takes place from father to son, but also because hepatitis is not a specific disease to children for whom women have many interests. The survey data have shown that species, $C$ tinctorium, $C$. sieberiana and $S$. latifolius are the best known species in these localities in the treatment of liver diseases with respectively citation index of 13, 5 and 4. Several studies have shown that Cochlospermum tinctorium, which is the most widely used species, has hepatoprotective properties (Etuk et al., 2009). By comparing the listed species with those of the literature consulted, it is found that they are used in traditional medicine in other countries for the management of liver diseases (Guinnin et al., 2015; Sangaré et al., 2012). The leaves were the most used organs as indicated by some studies (Megersa et al., 2013); but other studies (Teklehaymanot, 2009) have shown that roots are the most commonly used organs of traditional medicine. Seventy-four percent $(74 \%)$ of the receipts are decocts, which are close to those of Afolayan and Wintola (2014) who found $61 \%$. However, these results are contrary to those of Gueye et al. (2012) who found that $57 \%$ of the recipes were macerated.

\section{Antioxidant Activities and Phenolic Compounds}

Hepatitis B or $\mathrm{C}$ virus infection causes free radicals to be produced in order to destroy the virus. These free radicals, produced in excess, attack the lipid and protein constituents of the hepatocytes and cause cellular lesions (Gulam Waris and Haseeb Ahsan, 2006). These lesions may develop, in the event of chronicity to fibrosis, cirrhosis and hepatocellular carcinoma. Antioxidants, known for their anti-free radical properties, could be a therapeutic means in viral hepatitis. In this study, both tests (ABTS and FRAP) showed that the extracts contained antioxidants. The FRAP test expresses the potential of the extracts to supply electrons to ferric ions $\left(\mathrm{Fe}^{3+}\right)$ in order to reduce them to ferrous ions $\left(\mathrm{Fe}^{2+}\right)$ (Wojdylo et al., 2007). This shows that the extracts contain reducing compounds capable of allowing them to react with the free radicals by converting them into stable products. All the extracts studied could be classified as having a strong reducing power according to the classification of Wojdylo et al. (2007), which shows that 
extracts which have a reducing power greater than $5 \mu \mathrm{M} \mathrm{ET/g}$ are said to be extracts with a high reducing power. The ABTS test reveals that the extracts have the ability to stabilize the $\mathrm{ABTS}^{\circ+}$ cationic radical by trapping. This shows the ability of the extracts to trap free radicals. Molecules in the extracts transferred hydrogen to the radical to neutralize it (Mukherjee et al., 2011).

A low correlation $\left(\mathrm{R}^{2}=0.63\right)$ has been obtained between total phenolic contents and TEAC antioxidant capacities of the extracts compared to that obtained 0.94 by Ewa et al. (2009). This could be explained, on the one hand, by the non-specificity of the Folin-Ciocalteu reagent to phenolic compounds (Athamena et al., 2010) and on the other hand by the existence in the extracts of other non-phenolic compounds with antioxidants properties such as carotenoids, sterols, terpenoids. Studies have reported that the roots of $C$. sieberiana possess antioxidant power (Nartey et al., 2012) and contain terpenes, sterols, polyphenols and flavonoids (Traoré et al., 2015). Tannins, flavonoids and terpenoids have been characterized in the leaves of D. mespiliformis (Dangoggo et al., 2012). Studies have also reported that root and leaf extracts of $P$. thonningii have good antiknocking activities ABTS and FRAP (Dieng et al., 2017). Other studies have shown that the roots of $P$. thonningii contain tannins, terpenoids but do not contain flavonoids (Amon et al., 2013), while the leaves contain flavonoids, tannins and terpenoids (Kwaji et al., 2010). Flavonoids and tannins were characterized in the leaves of $S$. latifolius (Edewor et al., 2015). Koné et al. (2012) showed that the roots of $T$. macroptera contain flavonoids and possess good antioxidant capacity (TEAC). These species would therefore be rich in antioxidant compounds that could protect the liver from the oxidative stress caused by hepatitis viruses (Haque et al., 2014).

\section{Conclusion}

The study has gathered traditional medical knowledge of the province in the field of the management of liver diseases. The results obtained thus constitute a safeguard of the local knowledge and especially the materials for a scientific evaluation of the pharmacodynamics substances of the listed species. The results of preliminary phytochemical evaluation thus make it possible to affirm that the phenolic compounds are not the only compounds responsible for the antioxidant activity of the aqueous extracts of the most cited plants, here evaluated. Other types of extracts, in addition to this, should be carried and tested in vitro and in vivo in order to better apprehend their hepatoprotective activity.

\section{COMPETING INTERESTS}

The authors declare that they have no competing interests.

\section{AUTHORS' CONTRIBUTIONS}

The survey and sample collection were carried out by ENS. ENS, JYN, TKT, participated in the extraction, the determination of polyphenols and the antioxidant tests. The results obtained were statistically analyzed by ENS and AT. The work was supervised by NO, AT, AH, PIG and OGN. Finally, the writing of the manuscript was done by ENS, NO, AT and AH.

\section{ACKNOWLEDGEMENTS}

The authors thank Dr. AMADE OUEDRAOGO, Botanist at the UFR/SVT of the Ouaga I University Pr Joseph KI-ZERBO, for the authentication of the species inventoried. The authors are also grateful to the regional health department of the Cascades as well as to the traditional healers and herbalists of the locality for their frank collaboration.

\section{REFERENCES}

Abdel-Hameed. 2009. Total phenolic contents and free radical scavenging activity of certain Egyptian Ficus species leaf samples. Food Chemistry, 114: p12711277.

DOI: https://doi.org/10.1016/j.foodchem.2008. 11.005

Afolayan AJ, Wintola OA. 2014. A survey of medicinal plants used in the treatment of dysentery in amathole district municipality, South Africa. Pak. J. Bot., 46(5): 1685-1692.

Amon TT, Vershima AJ. 2013. Phytochemical evaluation and antibacterial activity: A comparison of various extracts from some Nigerian trees. Peak Journal of 
Medicinal Plant Research, 1(2): 13-18. DOI: 10.13140/RG.2.2.30726.16966

Athamena S, Chalghem I, Kassah-Laouar A, Laroui S, Khebri S. 2010. Activité antioxydante et antimicrobienne d'extraits de Cuminum cyminum L. Lebanese. Science Journal, 11(1): 69-81.

Dangoggo SM, Hassan LG, Sadiq IS, Manga SB. 2012. Phytochemical Analysis and Antibacterial Screening of Leaves of Diospyros Mespiliformis and Ziziphus Spina-Christi. Journal of Chemical Engineering, 1(1): 31-35.

Dieng SIM, Fall AD, Diatta-Badji K, Sarr A, Sene M, Sene M, Mbaye A, Diatta W, Bassene E. 2017. Evaluation de l'activité antioxydante des extraits hydroethanoliques des feuilles et écorces de Piliostigma thonningii Schumach. Int. J. Biol. Chem. Sci., 11(2): 768-776. DOI: https://dx.doi.org/10.4314/ijbcs.v11i2.19

Edewor TI, Owa SO, Oladipupo SS, Oyelakin RA. 2015. Determination of the Total Phenolic, Flavonoid Contents; Antioxidant Activity and GC-MS Study of the leaves of the Medicinal Plant Sarcocephalus latifolius. Int. J. Pharm. Sci. Rev. Res., 34(2): 82-86.

Etuk EU, Francis UU, Garba I. 2009. Regenerative action of Cochlospermum tinctorium aqueous root extract on experimentally induced hepatic damage in rats. African Journal of Biochemistry Research, 3(1): 001-004.

Ewa J-R, Marta Z-K, Janusz K. 2009. Antioxidant capacity, ascorbic acid and phenolics content in wild edible fruits. Journal of Fruit and Ornamental Plant Research, 17(2):115-120.

Gulam Waris, Haseeb Ahsan. 2006. Reactive oxygen species: role in the development of cancer and various chronic conditions. Journal of Carcinogenis, 5: 1-8. DOI: $10.1186 / 1477-3163-5-14$

Gueye M, Cissé A, Diatta CD, Diop S, Koma S. 2012. Etude ethnobotanique des plantes utilisées contre la constipation chez les Malinké de la communauté rurale de Tomboronkoto, Kédougou (Sénégal). Int. J. Biol. Chem. Sci., 6(2): 773-781.

DOI: http://dx.doi.org/10.4314/ijbcs.v6i2.19

Guinnin FDF, Sacramento TI, Sezan A, Ategbo J-M. 2015. Etude ethnobotanique des plantes médicinales utilisées dans le traitement traditionnel des hépatites virales $\mathrm{B}$ et $\mathrm{C}$ dans quelques départements du Bénin. Int. J. Biol. Chem. Sci., 9(3): 1354-1366. DOI: http://dx.doi.org/10.4314/ijbcs.v9i3.20

Haque A, Tahmina ASK, Sarker IR, Hossain M, Islam S, Islam A. 2014. Antioxidant and hepatoprotective effects of aqueous and ethanol extracts of Dendrophthoe falcata Linn leaves. Pharmacology OnLine, 1: 90-101.

Hinneburg I, Damien-Dorman HJ, Hiltunen R. 2006. Antioxidant activities of extracts from selected culinary herbs and spices. Food Chemistry, 97(1): 122-129. DOI: 10.1016/j.foodchem.2005.03.028

Koné D, Diop B, Diallo D, Djilani A, Dicko A. 2012. Identification, Quantitative Determination, and Antioxidant Properties of Polyphenols of Some Malian Medicinal Plant Parts Used in Folk Medicine. Macro to Nano Spectroscopy, 2012: 131-142, www.intechopen.com

Kwaji A, Bassi PU, Aoill M, Nneji CM, Ademowo G. 2010. Preliminary studies on Piliostigma thonningii Schum leaf extract: Phytochemical screening and in vitro antimalarial activity. African Journal of Microbiology Research, 4(9): 735-739.

Megersa M, Asfaw Z, Kelbessa E, Beyene A, Woldeab B. 2013. An ethnobotanical study of medicinal plants in Wayu Tuka District, East Welega Zone of Oromia Regional State, West Ethiopia. Journal of Ethnobiology and Ethnomedicine, 9(1): 68.

Mukazayire MJ, Minani V, Ruffo CK, Stévigny EB, Stévigny C, Duez P. 2011. Traditional phytotherapy remedies used in Southern Rwanda for the treatment of liver diseases. Journal of Ethnopharmacology, 138: 415- 431. DOI: 10.1016/j.jep.2011.09.025

Mukherjee S, Pawar N, Kulkarni O, Nagarkar B, Thopte S, Bhujbal A, Pawar P. 2011. Evaluation of free-radical quenching properties of standard Ayurvedic formulation Vayasthapana Rasayana. BMC Complementary and Alternative Medicine, 11: 38. DOI: 10.1186/14726882-11-38

Nartey ET, Ofosuhene M, Kudzi W, Agbale, CM. 2012. Antioxidant and gastric 
cytoprotective prostaglandins properties of Cassia sieberiana roots bark extract as an anti-ulcerogenic agent. US National Library of Medicine National Institutes of Health, p1-10

N'Guessan K, Kadja B, Zirihi GN, Traoré D, Aké-Assi L. 2009. Screening phytochimique de quelques plantes médicinales ivoiriennes utilisées en pays Krobou (Agboville, Côte-d'Ivoire). Sciences \& Nature, 6(1): 1-15

OMS, 2012. Prévention et lutte contre l'hépatite virale : Cadre pour l'action mondiale. WHO/HSE/PED/HIP/GHP 2012.1

OMS, 2014. Hépatites. Soixante-septième assemblée mondiale de la santé. http://www.who.int/csr/disease/hepatitis/ GHP

Re R, Pellegrini N, Prottegent A, Pannala A, Yang, M, Rice-Evans, C. 1999. Antioxidant activity applying an improved ABTS radical cation decolorization assay. Free Radical Biology and Medecine, 26(9/10): 12311237.

Sangaré MM, Sina H, Dougnon J, Bayala B, Ategbo J-M, Dramane KL. 2012. Etude ethnobotanique des plantes hépatotropes et de l'usage traditionnel de Gomphrena celosioides Mart. (Amaranthaceae) au Bénin. Int. J. Biol. Chem. Sci., 6(6): 5008-5021.

DOI http://dx.doi.org/10.4314/ijbcs.v6i6.20

Schwierz C, Thiry N, Van de Sande S. 2011. Évaluation économique du traitement antiviral de l'hépatite B chronique en Belgique - Tome 2. Centre fédéral d'expertise des soins de santé (KCE).

Singleton VL, Orthofer R, Lamuela-Raventós RM. 1999. Analysis of total phenols and other oxidation substrates and antioxidants by means of folin-ciocalteu reagent. In P. Lester (Ed.), Methods in Enzymology, 299: p152-178. DOI:
https://doi.org/10.1016/S00766879(99)99017-1

Teklehaymanot T. 2009. Ethnobotanical study of knowledge and medicinal plants use by the people in Dek Island in Ethiopia. Journal of Ethnopharmacology, 124(2009): $\quad 69-78 . \quad$ DOI: doi:10.1016/j.jep.2009.04.005

Thevenot T, Martino VD, Lunel-Fabiani F, Vanlemmens C, Becker M, Bronowicki J, Bresson-Hadni S, Miguet J. 2006. Traitements complémentaires de l'hépatite chronique virale C. Gastroenterol Clin Biol, 30: p197-214

Tibiri A, Rakotonandrasana O, Nacoulma GO, Banzouzi J.T. 2007. Radical Scavenging Activity, Phenolic Content and Cytotoxicity of Entada africana Guill. et Perr. (Mimosaceae). Journal of Biological Sciences, 7(6): 959-963. DOI: 10.3923/jbs.2007.959.963

Traoré L, Bekro Y, Pirat J, Bekro JA. 2015. Study of crude extracts from Cassia sieberiana root bark and Khaya grandifoliola trunk bark: phytochemical screening, quantitative analysis and radical scavenging activity. International Journal of Current Pharmaceutical Research, 7(3): 22-26.

Twedt DC. 2006. Nouvelles approches thérapeutiques des affections hépatiques: la SAMe. Pratique médicale \& chirurgicale de l'animal de compagnie, 41(4): 269-272.

WHO, 2004. Department of Measurement and Health Information. Estimated total deaths by cause and WHO Member State, 2002. www.who.int/evidence/bod

Wojdyło A, Oszmianski J, Czemerys R. 2007. Antioxidant activity and phenolic compounds in 32 selected herbs. Food Chemistry, 105: 940-949. DOI: https://doi.org/10.1016/j.foodchem.2007. 04.038 . 